\title{
"Hands of fame": a new tool to improve dedication of key opinion leader for hand hygiene
}

\author{
AF Widmer ${ }^{*}$, H Schuhmacher, S Tschudin-Sutter, the infection control team \\ From International Conference on Prevention \& Infection Control (ICPIC 2011) \\ Geneva, Switzerland. 29 June - 2 July 2011
}

\section{Introduction / objectives}

Compliance of hand hygiene is frequently less than optimal and heavily depends on the dedication of the key opinion leaders. There are few tools to support their role model for hand hygiene. Dedicated days, information campaigns and similar activities lead to tremendous, but short-lived impact on the hand hygiene compliance. Psychological studies have shown, that a public statement improves compliance with the statement. We therefore searched for a tool who to trigger a public long-term statement of the key opinion leaders of the hospital.

\section{Methods}

The University of Basel hospitals is a 900 bed tertiary care center with 5 Intensive CUs and kidney and bone marrow transplant program. In January 2011, all key opinion leaders of the university hospital were asked to participate in an action to imprint both their hands on a flagstone of $80 \times 80 \mathrm{~cm}$. The composition of the flagstone is a composite plastic, that allows to imprint the hands, and is fixed within one hour. In addition, the names are placed on the flagstone to indicate.

\section{Results}

Of the 21 key opinion leaders, 20 participate in the study. Flagstone with the hands of the individuals were placed in the main entrance of the hospital restaurant. The names of each participant is placed on the flagstone in copper letters to remind the individual as the healthcare workers of proper hand hygiene. The half-life of

Infectious disease and Hospital epidemiology, University of Basel, Basel, Switzerland the $40 \mathrm{~kg}$ flagstone (total of $880 \mathrm{~kg}$ transported) is approximately, 25 years.

\section{Conclusion}

Imprinted flagstones placed in the hospital area allows to motivate key opinion leaders for hand hygiene. The "hands of fame" flagstones are a new tool to remind each opinion leader on a daily basis on their commitment for hand hygiene. The long-half life of flagstones will likely exceed the lifetime of the individual.

\section{Disclosure of interest}

None declared.

Published: 29 June 2011

doi:10.1186/1753-6561-5-S6-P107

Cite this article as: Widmer et al:: "Hands of fame": a new tool to improve dedication of key opinion leader for hand hygiene. BMC Proceedings 2011 5(Suppl 6):P107.

Submit your next manuscript to BioMed Central and take full advantage of:

- Convenient online submission

- Thorough peer review

- No space constraints or color figure charges

- Immediate publication on acceptance

- Inclusion in PubMed, CAS, Scopus and Google Scholar

- Research which is freely available for redistribution 